\title{
LA MÁSCARA Y EL AGÓN: EURÍPIDES Y NIETZSCHE
}

\author{
Roberto Pastor Cristóbal \\ Doctorando, Universidad de La Rioja \\ cal.sandie@hotmail.com
}

\begin{abstract}
RESUMEN: El propósito de este trabajo es estudiar la presencia del trágico griego Eurípides en la obra nietzscheana hasta 1876. El análisis no sólo busca describir las palabras del filósofo alemán en torno a la materia, sino que, también, pretende determinar la importancia que un personaje de la Antigüedad pudo tener en la labor de interpretación crítica del desarrollo artístico/filosófico de la civilización occidental por parte de Nietzsche.
\end{abstract}

Palabras clave: Eurípides, Nietzsche, tragedia, filología, recepción.

\section{THE MASK AND THE AGON: EURIPIDES AND NIETZSCHE}

ABSTRACT: The aim of this paper is to study the presence of the Greek thespian Euripides in Nietzschean work until 1876. The survey not only wants to describe the German philosopher's words but also it will be important to find how an ancient personality could be useful to Nietzsche in order to make a critical interpretation of the Western Civilization artistic and philosophical development.

Keywords: Euripides, Nietzsche, tragedy, philology, reception.

Recibido: 4 de noviembre de 2017 Aceptado: 29 de Diciembre de 2017 


\section{Introducción}

El arte y el pensamiento trágicos exigen un difícil equilibrio entre lo apolíneo y lo dionisíaco, sus interacciones, sus juegos de máscaras. Todo ello empezó a quebrarse -como explica Nietzsche- con la introducción del diálogo en la tragedia, con la pérdida de importancia del coro (elemento dionisíaco) a favor de la escena. Y acabó finalmente desnaturalizado con la introducción por Eurípides (de la mano de Sócrates) de radicales novedades en la tragedia que acabaron dando paso a otro tipo de arte: dialéctico, racional y moral, reflejo de la filosofía socrática ${ }^{1}$.

Juan Manuel Medrano Ezquerro, El reino celestial del cambio

El conocimiento nace del saberse ignorante. Esta investigación surgió al aparecer una figura totalmente inesperada en los sucesos que, según Friedrich Nietzsche, condujeron a lo que él denominó como «la muerte de la tragedia». Es bien conocida la imagen de una lucha Agonal entre espíritus dionisiaco y apolíneo que condujo al nacimiento y posterior desarrollo de la tragedia, una de las más sublimes creaciones artísticas del mundo griego. Tampoco es desconocida la idea de que con la llegada de Sócrates el mundo trágico llegó a su fin; sustituido por la prosa, la racionalidad y una nueva moral no agonal. Sin embargo, al leer la cita de Medrano Ezquerro se puede observar que fue, precisamente, un trágico el que ejecutó en el plano creativo los nuevos principios del socratismo. Eurípides es el protagonista de esta historia, pero ¿quién era Eurípides para Nietzsche?

(...) en cierto sentido Eurípides no era más que una máscara a través de la cual hablaba una divinidad, una divinidad que no era Dioniso o Apolo, sino un tipo de daimon recién nacido llamado Sócrates. He aquí la nueva oposición -lo dionisiaco contra lo socrático- que hizo perecer a la obra artística de la tragedia griega ${ }^{2}$.

La máscara, elemento por otra parte tan propio de la dramaturgia helena, no puede evitar ciertas preguntas. ¿No es este Eurípides el autor de Las bacantes?, ¿no es una de las principales fuentes para el estudio de Dioniso y su culto?, ¿acaso no sometió a sus personajes a las pasiones y los destinos de lo trágico?, ¿de dónde proviene, por lo tanto, la invectiva nietzscheana contra el autor griego?

1. Medrano, J. M., El reino celestial del cambio. Nietzsche y la religión. Madrid, Síntesis, 2016, p. 140.

2. Nietzsche, F., El nacimiento de la tragedia griega o helenismo y pesimismo. Barcelona 2014, p. 85. 
La hipótesis de partida para poder responder a todas estas cuestiones, para solucionar la aparente contradicción entre el «Eurípides nietzscheano» y el «Eurípides histórico», es vislumbrar que, posiblemente, el trágico heleno pudo ser más significativo, de lo que a primera vista podría parecer, en el marco de la producción del filósofo alemán en torno al mundo de la Grecia antigua. Por un lado, en la literalidad de la cita de El nacimiento de la tragedia, Eurípides fue una suerte de enlace entre la producción trágica y las ideas socráticas. A esto se podría sumar un Eurípides como concepto o idea, su equivalencia a «la muerte de la tragedia». Por otro lado, no sería superfluo ir más allá de lo filosófico. Eurípides también pudo representar para Nietzsche una estética o planteamientos artísticos singulares y a los que debía enfrentarse. ${ }^{3}$

Se podría objetar que lo enunciado hasta este punto son puras conjeturas, producto más de una curiosidad como lector que del rigor del método científico. Por este motivo, es preciso construir a continuación un estado de la cuestión que permita saber por dónde se ha movido la investigación en torno a la relación entre Nietzsche y Eurípides. Las publicaciones que se van a analizar están ordenadas siguiendo un criterio que parte de lo general para llegar a lo más específico, desde la reflexión en relación a lo trágico hasta aquellas publicaciones que han trabajado el rol que pudo tener Eurípides en lo nietzscheano.

Si hubiera que comenzar por algún punto, sin duda, sería por la polémica habida con Ulrich von Wilamowitz-Moellendorf a raíz de la publicación en 1872 de El nacimiento de la tragedia por el joven catedrático de Basilea. El debate se centró en la precisión del trabajo de Nietzsche a nivel filológico, pues como la labor de un filólogo fue entendida la obra en aquella época; ello a pesar de los intentos de Erwin Rohde por defender las tesis nietzscheanas, aduciendo que toda reflexión sobre la creación artística también debe ser producida con un estilo alejado de aurea mediocritas académica ${ }^{4}$. Wilamowitz realizó una crítica detaIlada a la publicación por faltar ésta a la verdad científica. Precisamente, fue en torno a Eurípides donde la reseña de Wilamowitz tuvo uno de sus puntos más subrayables. Atacó a Nietzsche desmontando la idea de un Eurípides como un mal trágico, más bien era lo contrario según la tesis del princeps philologorum ${ }^{5}$.

Con estos comienzos, Nietzsche no estuvo muy bien posicionado en el campo de la recepción contemporánea de la figura de Eurípides, la cual fue cada vez más positiva, contrastando con la habida negativamente en las primeras décadas del siglo XIX. Pero desde la segunda mitad del siglo XX y hasta la ac-

3. En relación al interés de Nietzsche por la estética véase: Herrero Senés, J., La inocencia del devenir: la vida como obra de arte según Friedrich Nietzsche y Oscar Wilde, Madrid 2002.

4. Rohde, E., "Reseña para la Litterarische Centralblatt", en Rohde, E., Wilamowitz-MoeIlendorf, U. von y Wagner, R., Nietzsche y la polémica sobre El nacimiento de la tragedia. Génesis de una disputa académica. Málaga 1994, p. 46.

5. Wilamowitz, U. von, “FFilología del futuro!”, Rohde, E., Wilamowitz-Moellendorf, U. von y Wagner, R., Nietzsche y la polémica... pp. 80-92. 
tualidad ha habido un creciente interés por un Nietzsche que fuera más allá de su juventud filológica o de la caricatura nacionalsocialista de éste. En el ámbito internacional ha habido una serie de trabajos que han reflexionado en torno a las primeras producciones nietzscheanas relativas a la antigüedad helénica.

E. R. Dodds en su trabajo sobre Dioniso recupera al Nietzsche que propuso al dios como metáfora de los elementos irracionales, vitales e impulsivos de lo trágico ${ }^{6}$. Dodds, sin embargo, no fue tan categórico con Eurípides como lo fue el pensador germano. Destacó, más bien, las ambigüedades del primero por ser tanto un producto de la llustración ateniense como un autor centrado en lo irracional: «Eurípides, entonces, si estoy en lo cierto acerca de él, representa no sólo a la llustración, sino también a la reacción contra ésta. En cualquier caso, reaccionó contra la psicología racionalista de algunos de sus exponentes y la astuta inmoralidad de los demás ${ }^{7}$. Es una reflexión alejada de lo nietzscheano y que conecta a Eurípides más con Dioniso que con Sócrates.

Paul de Man, en un artículo de 1972 en el que realizó una deconstrucción lingüística de El Nacimiento de la tragedia, resaltó el carácter premeditadamente complejo y heterogéneo de la mencionada obra: «Los vínculos narrativos son tan débiles que uno puede sentirse tentado de poner la unidad del texto en cuestión por razones puramente filológicas, sobre la base de que el complejo comienzo de $\mathrm{El}$ nacimiento de la tragedia convierte el producto final en un mosaico de fragmentos desconectados o, como el mismo Nietzsche lo puso: en un "centauro" $»^{8}$. Estas palabras no necesariamente implican defecto en el estilo nietzscheano sino una intención: la de ligar conceptos antitéticos; por ejemplo, la Antigüedad con la Modernidad. En este punto es donde las palabras de Paul de Man cobran sentido. Eurípides sería el anticipo de otros casos, como el del más moderno Lessing, de literatos racionalistas-moralistas bajo la aparente forma de lo trágico 9 .

Walter Kaufmann también quiso explorar la complejidad del lenguaje nietzscheano. ¿Qué quiere decir el filósofo cuando habla de que el trágico no es sino una máscara de Sócrates? Nietzsche no acaba de construir un personaje históricamente creíble, parece más un rol previamente asignado que una figura de carne y hueso ${ }^{10}$. Posteriormente, en Tragedia y filosofía (1978), Kaufmann profundizó la relación entre Nietzsche y la tragedia. El filósofo ensanchó los

6. Dodds, E. R., The Greeks and the Irrational. Berkeley/London 1951.

7. Las traducciones de los fragmentos procedentes de ediciones no españolas son todas del autor del presente texto. Dodds, E. R., The Greeks and... p. 187.

8. De Man, P., "Genesis and Genealogy in Nietzsche's The Birth of Tragedy". Diacritics Vol. 2, 4 (1972), p. 46.

9. De Man, P., "Genesis and Genealogy... p. 50.

10. Kaufmann, W., Nietzsche. Philosopher, Psychologist, Antichrist. Princeton (NJ) 1974, p. 393. 
límites, de un a priori género literario, dotándolo de un carácter filosófico ${ }^{11}$. Fue un valor positivo de acuerdo con la perspectiva de Kaufmann. Por el contrario, no lo fue tanto la concepción de lo trágico como pesimismo. Si se compara a Esquilo (el trágico más perfecto según Nietzsche) con Eurípides (el más imperfecto) vemos que en el primero existe un final no necesariamente desdichado sino de concordia, de posibilidad de acuerdo entre el héroe y la moira. En Eurípides es todo lo contrario, es pura fatalidad irremediable. La tragedia permitió lo uno y lo otro, la rotundidad nietzscheana fue, en este caso, equivocada ${ }^{12}$.

M. S. Silk y J. P. Stern introdujeron una idea harto sugerente para entender al Eurípides de Nietzsche: el arquetipo ${ }^{13}$. Los personajes y los dioses que aparecen en El nacimiento de la tragedia deben ser entendidos más como nociones abstractas que como entes humanos. Eurípides puede ser interpretado de esta manera. Sin embargo, los autores también reconocen que éste es un caso singular pues el trágico aparece con una mayor personalidad basada en sus debilidades o en los gustos que éste tuvo y que ciertas fuentes primarias que así lo atestiguaron en su momento, todo ello le dotó de un cierto "carácter» ${ }^{14}$.

En el contexto español, las recientes décadas también han asistido a una mayor atención en torno al filósofo alemán y existen una serie de estudios monográficos que pueden resultar de bastante interés para la presente investigación ${ }^{15}$. El primero de ellos es el de Elvira Burgos, que en 1993 publicó Dioniso en la filosofía del joven Nietzsche. En él, la autora destaca que Nietzsche quiso explicar los cambios habidos en el género trágico por culpa de un excesivo intelectualismo por parte de Eurípides ${ }^{16}$. Éste sería un autor principalmente teorizante.

Barrios Casares ha enfatizado los diversos niveles que El nacimiento de la tragedia puede tener como lecturas. Dichas lecturas van asociadas a dos influencias clave en el joven Nietzsche como son Wagner, que posibilitaría una lectura cultural, y Schopenhauer, que le daría el fondo filosófico ${ }^{17}$. Para Barrios Casares, la principal lectura que se puede hacer de Eurípides es la filosófica, el de la expresión práctica del diálogo socrático en la tragedia: «Sólo con Eurípides se precipita la agonía del espíritu trágico-dionisiaco porque en sus obras se produce el tránsito desde el diálogo apolíneo hasta la dialéctica socrática, que ya

11. Kaufmann, W., Tragedia y filosofía. Barcelona 1978, p. 217.

12. Kaufmann, W., Tragedia y filosofía, p. 258.

13. Silk, M. S. y Stern, J. P., Nietzsche on Tragedy. Cambridge/New York/Melbourne 1984, p. 155.

14. Silk, M. S. y Stern, J. P., Nietzsche on... p. 262.

15. Para contextualizar mejor las intenciones del Nietzsche filólogo y su relación con la ciencia de su época véase: Gutiérrez Girardot, R., Nietzsche y la filología clásica. Málaga 1997 o Cano, G., Nietzsche y la crítica de la Modernidad. Madrid 2001.

16. Burgos, É., Dioniso en la filosofía del joven Nietzsche. Zaragoza 1993, p. 35.

17. Barrios Casares, M., Voluntad de lo trágico. El concepto nietzscheano de voluntad a partir de "El nacimiento de la tragedia". Madrid 2002, p. 83. 
no se contenta con compartir su protagonismo con el otro elemento integrante de la vida y la cultura de los griegos, sino que quiere dominar por completo ${ }^{18}$.

Esteban Enguita, en cambio, observa que Nietzsche reduce las principales cuestiones en torno al desarrollo de la tragedia a un problema de cultura, en sendos fragmentos: "La política desarrolla en su esfera la visión dionisiaca del mundo y ocupa un lugar secundario pero ineludible dentro de esta totalidad: está subordinada a la metafísica de la cultura y es un instrumento imprescindible para la realización de los fines prácticos propuestos por esa metafísica» ${ }^{19}$. También señala: «Resultaría una tarea baldía abordar el pensamiento político del joven Nietzsche si se ignorara el papel central que para esta cuestión representa la idea de cultura (Kultur), y no sólo desde un punto de vista teórico, puesto que el problema de la cultura contiene un proyecto pedagógico y, en sus márgenes, unas líneas generales para la acción política orientados ambos a la creación de una cultura verdadera (la cultura trágica) cuyo éxito pasa necesariamente por el enfrentamiento victorioso contra el tipo de cultura (civilización) que prevalece en la época moderna y la seudocultura dominante en Alemania ${ }^{20}$. Eurípides aparece reflejado, siguiendo la interpretación de este autor, como un poeta de la Ilustración ${ }^{21}$. Y, por ello, plenamente consecuente con el cambio cultural hecho por Sócrates, el de la ciencia que sustituye al mito trágico como referente de interpretación de la vida ${ }^{22}$.

González Varela ha calificado a Nietzsche como un crítico de la Modernidad $^{23}$. En un diálogo permanente pasado/presente, el filósofo alemán vio al Eurípides socrático como un precedente de los pensadores europeos del siglo XIX revolucionario, la época del propio Nietzsche: «La Grecia de Sócrates y Eurípides es auscultada por Nietzsche con un ojo completamente fijado en la situación caótica de la Europa de su tiempo y, en particular, de Francia, devastada por un permanente ciclo revolucionario cuyo culmen momentáneo era la Comuna de París ${ }^{24}$.

Hasta ahora se han expuesto reflexiones generales. Sin embargo, aunque más escasas, existen publicaciones concretas sobre el papel de Eurípides en la obra y pensamiento nietzscheanos. Estas diferentes propuestas van a ser tratadas más en profundidad en apartados subsiguientes, con lo que aquí únicamente se señalarán algunos de los aspectos más significativos.

Una de los primeros estudios fue el de Rafael Angel Herra (1967) que fue bastante seguidor del discurso nietzscheano en el sentido de que resumió la par-

18. Barrios Casares, M., Voluntad de... p. 92.

19. Esteban Enguita, J. E., El joven Nietzsche. Política y tragedia. Madrid 2004, p. 16.

20. Esteban Enguita, J. E., El joven Nietzsche... p. 37.

21. Esteban Enguita, J. E., El joven Nietzsche... p. 122.

22. Esteban Enguita, J. E., El joven Nietzsche... p. 65.

23. González Varela, N., Nietzsche contra la democracia. Madrid 2010, pp. 58-60.

24. González Varela, N., Nietzsche contra... p. 109. 
ticipación de Eurípides como la de la ruptura de la «paradoja» existente entre lo dionisiaco y lo apolíneo mediante la racionalización, suponiendo el final del mito como referencia ${ }^{25}$. Michael Hinden (1981) realizó un análisis muy detaIlado de la problemática que existe en el Eurípides de Nietzsche, en su visión moralista, racionalista y el lugar de Las bacantes ${ }^{26}$. Muy a subrayar es la idea de una cierta conexión psicológica entre Nietzsche y Eurípides, la cuál va estar presente en esta investigación ${ }^{27}$.

Lo mismo, en cuanto a nivel de detalle, podría decirse de la publicación de Albert Henrichs (1986), que estableció la profunda dependencia nietzscheana de un tipo de fuentes (ej. Aristófanes) y escuelas interpretativas (ej. Hermanos Schlegel $)^{28}$. También dio cuenta de la contradictoria relación entre Nietzsche y Las bacantes, fuente y rechazo en torno a la noción de lo dionisiaco ${ }^{29}$. No se puede obviar, por último, el trabajo de Mora Mínguez (2014) centrado en una de las fuentes de Nietzsche respecto a la figura de Eurípides: Diógenes Laercio, aunque por lo demás no señala nada destacable en comparación con el resto de estudios comentados ${ }^{30}$.

Si se hace una valoración general del estado de la cuestión se puede concluir que la cuestión euripidea es relevante, que aparece casi siempre asociada a Sócrates y lo socrático, además de la importancia que tuvo para Nietzsche en relación a interpretar críticamente su propia contemporaneidad. Aún así, este estudio defiende que son las ambigüedades y no las sentencias nietzscheanas las que más interés pueden tener en relación a la cuestión planteada, algo que los estudios tratados también comparten en parte.

Hay, por todo ello, un doble objetivo en este análisis de la presencia de Eurípides en Nietzsche. En primer lugar, es preciso describir las principales conclusiones del pensador germano en torno a la figura del autor trágico. No sólo a partir de El nacimiento de la tragedia, sino teniendo presentes otras fuentes. Para hacer la investigación más manejable, se ha optado por circunscribir el ámbito de estudio hasta 1876, ya que fue en esta primera etapa donde lo griego, y por lo tanto Eurípides, tuvieron una mayor presencia en la producción del filósofo.

25. Herra, R. A., "La disonancia hecha carne: Nietzsche y la muerte de la tragedia". Revista de Filosofía de la Universidad de Costa Rica 20 (1967), pp. 35-40.

26. Hinden, M., "Nietzsche's Quarrel With Euripides". Criticism Vol. 23, 3 (1981), pp. 252, 254, 254-255.

27. Hinden, M., "Nietzsche's Quarrel... pp. 259-260.

28. Henrichs, A., "The Last of the Detractors: Friedrich Nietzsche's Condemnation of Euripides". Greek, Roman and Byzantine Studies Vol. 27, 4 (1986), pp. 370-390.

29. Henrichs, A., "The Last of the Detractors... pp. 390-397.

30. Mora Mínguez, T. M., "Nietzsche, Eurípides, Diógenes: el 'imposible diálogo' en la inversión de valores desde la desmitificación griega a la secularización moderna. Comentario a los párrafos 12 y 13 de El nacimiento de la tragedia". HYBRIS. Revista de Filosofía Vol. 5, especial (2014), pp. 87-97. 
Una vez hecho esto, habrá que definir los posibles significados de Eurípides, interpretar qué nos quiso decir Nietzsche en esta materia. Ello exige un enfoque amplio, que tenga en cuenta los trabajos de clasicistas, germanistas o filósofos. Hay nociones, como «la ansiedad de la influencia» o la tradición y recepción clásicas, con conceptos como lo agonístico, la máscara, lo trágico, que han actuado como perspectivas inspiradoras para la presente investigación ${ }^{31}$. Los conceptos mencionados están presentes a un nivel genérico, no técnico, ya que cada uno de ellos merecería un capítulo aparte.

Lo que sí ha merecido una mayor atención, con carácter previo y para una mejor contextualización, ha sido la relación de Nietzsche con el mundo griego, la cual tendrá un capítulo a continuación. De esta manera, se podrá comprender mejor el «combate agonal» entre Nietzsche y Eurípides.

\section{Nietzsche y el mundo helénico}

Cuando en 1858 Nietzsche se trasladó a la Schulpforta de Naumburg se produjo uno de sus primeros contactos con el mundo clásico, ya que su historia, sus lenguas y la literatura grecolatinas fueron uno de los puntales de la enseñanza de dicha institución. En palabras de Girardot: «No cabe duda de que en Pforta Nietzsche se entregó plenamente al espíritu de la llamada época de Goethe en todas sus ambiciones y propósitos $»^{32}$. Y tal espíritu estaba invadido por un afán de conocimiento sobre el mundo antiguo que incluyó también la etapa universitaria que en el caso de Nietzsche le ocupó desde 1864 hasta 1869 en Bonn y Leipzig. Esta etapa, Ernst Nolte la ha denominado como "griega» en la plenitud de la palabra ${ }^{33}$. Aunque el joven Nietzsche comenzó estudios teológicos, siguiendo la estela de su padre, estos le ofrecieron un bagaje en el estudio de lenguas clásicas, además del contacto con el que pasó a ser el principal mentor de Nietzsche: Friedrich Ritschl. Paulatinamente Nietzsche acabó derivando hacia los estudios filológicos publicando una serie de trabajos que fueron bien acogidos, por ejemplos sobre el aristocrático Teognis, presagiando preocupaciones e intereses posteriores ${ }^{34}$.

Con los datos expuestos, aunque conocidos, se quiere ofrecer la imagen de una juventud íntimamente ligada a lo griego, pero para entenderla también será preciso conocer la fuerte vinculación que desde finales del siglo XVIII se venía produciendo entre la cultura alemana y el pasado heleno. El

31. Las referencias existentes en torno a estas cuestiones son casi infinitas, pero hay dos ejemplos que pueden ser señalados: Highet, G., La tradición clásica 2 Vols. México D. F. 1996 y Bloom, H., La ansiedad de la influencia: una teoría de la poesía. Madrid 2009.

32. Gutiérrez Girardot, R., Nietzsche y la... p. 26.

33. Nolte, E., Nietzsche y el nietzscheanismo. Madrid 1990, p. 38.

34. Nolte, E., Nietzsche y el... p. 36. 
origen de ello se encuentra en dicho siglo porque, a diferencia de Italia con el Renacimiento (s. XVI) o Francia con su movimiento clasicista (s. XVII), los fragmentados estados alemanes habían retrasado el redescubrimiento de lo clásico debido a los estragos de los conflictos religiosos y la división política de los dos primeros siglos de la Edad Moderna. El verdadero «Renacimiento» de la cultura germana tuvo que esperar a un siglo más apacible como el XVIII y vivir su propia fascinación con el pasado, independiente de modelos como los citados italiano o francés.

De hecho, es gracias a autores alemanes como Winckelmann a los que debemos un verdadero interés por lo griego en Europa, en contraste con la anterior atención prestada a lo romano. Lo griego fue percibido, a partir de ahora, como lo más perfecto, como el espíritu «del ideal desplegado en la historia y, no obstante, identificado con la naturaleza» ${ }^{35}$. El antiguo mundo helénico es la nueva utopía para el pueblo alemán. Un importante caudal de mitología que está al servicio de la creación artística ${ }^{36}$.

Dos visiones pueden resumir el uso que tuvo el legado de la tradición griega. Por un lado, estuvo el clasicismo más interesado en lo formal y sus valores pedagógicos. Por ejemplo, Lessing utilizó la forma trágica adaptando únicamente el contenido e introduciendo al hombre moderno en lugar del héroe clásico ${ }^{37}$. Por otro lado, Hölderlin vio la pureza de la Antigüedad también en el contenido, aunque no exento de paralelismos más modernos como la trinidad: Dioniso/ Cristo/Empédocles ${ }^{38}$. Mas en un tercer giro, será el Romanticismo el que intente lograr la síntesis perfecta de ambas posiciones. Autores como Goethe, SchiIler, Novalis quisieron renovar la cultura alemana, visionando una unión entre poesía y mitología, tal y como ellos percibieron que debió ser en la época de Homero o los grandes trágicos ${ }^{39}$.

El concepto de lo trágico tuvo para estos románticos un triple significado según Peter Stein: el del «humanista» erudito, el «nacional» de fuentes para una cultura propia y el «universal» que dota de sentido a la reflexión sobre lo huma$\mathrm{no}^{40}$. Los hermanos Schlegel, Friedrich y August, tuvieron mucho que ver en este sentido porque desarrollaron toda una teoría literaria en base a lo antiguo ${ }^{41}$. Por

35. Miller, N., "El filohelenismo europeo entre Winckelmann y Byron", VV.AA., Akal Historia de la Literatura y Sociedad en el mundo occidental. Vol. 4. Ilustración y Romanticismo, 1700-1833. Madrid 1992, p. 313.

36. Stephan, I., "Período artístico (Clasicismo-Romanticismo)", VV.AA., Historia de la literatura alemana. Madrid 1989, pp. 194-199.

37. Shipley, J. T., "Tragedia", Shipley, J. T., Diccionario de la literatura mundial. Crítica, formas, técnica. Barcelona 1973, p. 526.

38. Véase Hölderlin, F., La muerte de Empédocles: tragedia. Madrid 1988.

39. Stephan, I., "Período artístico... p. 195.

40. Stein, P., "Período artístico... p. 223.

41. Behler, E., "A. W. Schlegel and the Nineteenth-Century Damnatio of Euripides". GRBS 27,366 . 
ejemplo, para F. Schlegel, lo clásico consiguió cotas de equilibrio jamás antes alcanzadas gracias a aunar la pasión y lo racional, siendo la tragedia una de las manifestaciones de este sentido de entender lo griego ${ }^{42}$.

Volviendo a Nietzsche, se puede afirmar que en él vivieron las dos almas del interés por lo clásico. Tanto un interés filológico, como un interés filosófico, que traían de vuelta a la Antigüedad griega para ayudar a explicar la Modernidad. Un pensador esencial en esta materia fue Arthur Schopenhauer, que reflexionó ampliamente sobre lo trágico de la existencia. Para autores como Nolte, la lectura dionisiaca/apolínea de lo trágico vino dada por dar un carácter mitológico al binomio schopenhaueriano de «voluntad» y «representación» ${ }^{43}$. Otra lectura que Nietzsche pudo tener fue la de Kierkegaard, puesto que el danés tuvo a bien comparar las diferencias entre el espíritu trágico antiguo y el moderno, de enfrentar la inocencia, la tristeza genuina y el objetivismo antiguos con el sentimiento de culpa, lo cómico y el subjetivismo moderno ${ }^{44}$.

Para Nietzsche no fueron únicamente destacables las lecturas literarias o filosóficas porque su formación fue esencialmente filológica y a ello esta investigación también ha de prestar la debida atención. De la ciencia filológica de la época puede decirse que estaba, en aquel entonces, viviendo un proceso de profesionalización donde el método científico y el análisis crítico de textos eran sus principales banderas. Maestros y sus discípulos competían por sentar, nunca mejor dicho, cátedra. La posterior disputa con Wilamowitz puede ser entendida bajo este prisma. La relación de Nietzsche con la filología es uno de los puntos cruciales para entender lo que él vio en el mundo griego, y posteriormente en Eurípides. Si nos atenemos a las opiniones de algunos estudiosos de Nietzsche observamos diferentes interpretaciones. Para uno de sus biógrafos, C. P. Janz, la filología era «un medio del que se servía y al que servía para conocer al hombre antiguo» ${ }^{45}$. Otros estudiosos, como Eugen Fink ven en lo filológico algo secundario para Nietzsche ${ }^{46}$.

Por el contrario, la investigación española sí ha creído que lo filológico tuvo un cierto valor dentro del pensamiento nietzscheano. Para autores como Sánchez Meca o Vicente Serrano, en sendas introducciones a obras sobre la antigüedad griega producidas por el filósofo alemán, la filología tuvo en Nietzsche un carácter pedagógico, capaz de ayudar a una "cura de la cultura moderna» y

42. Schlegel, F., On the Study of Greek Poetry. Albany (NY) 2011, p. 74.

43. Nolte, E., Nietzsche y el... p. 43.

44. Hubig, C., "Repliegue y desarrollo del genio artístico al yo existente. La filosofía y el arte tras la muerte de Goethe", VV.AA., Akal Historia de la Literatura y Sociedad en el mundo occidental. Vol. 5. La edad burguesa, 1833-1914. Madrid 1993, p. 60.

45. Janz, C. P., Friedrich Nietzsche. Vol. I. Infancia y su juventud. Madrid 1981, p. 107.

46. Fink, E., La filosofía de Nietzsche. Madrid 1986, p. 32. 
no se puede olvidar que el pensador germano partió de una tradición que siempre pesó mucho, aunque fuera para contradecirla ${ }^{47}$.

Pero ha sido Gutiérrez Girardot el que mejor ha definido el concepto de filología para Nietzsche, que no es sino la fusión entre la ciencia-conocimiento y el arte-creación ${ }^{48}$. Para este autor, Homero y la filología clásica (1869) es el mejor texto para entender lo dicho anteriormente y hay que recordar que, al ser su lección inaugural en Basilea, puede ser entendido como una especie de «programa». Para Girardot, Nietzsche parte de lo artístico como necesidad ${ }^{49}$. Pero, progresivamente, hay un acercamiento a la filosofía que culminará tras su «fracaso» como filólogo ante sus colegas ${ }^{50}$.

Se puede concluir, Ilegado este punto, que el devenir de Nietzsche acaba en crítica de la ciencia (crítica de lo filológico) porque, como un romántico consecuente, no entendió nunca el giro racionalista que a mediados del siglo XIX se venía produciendo en Europa. Es ahí donde su obra sobre Grecia y lo que dirá sobre Eurípides cobra sentido, es el contexto. Pero este apartado necesita tratar un punto más, las propias fuentes, ir al mismo Nietzsche. Y tal y como se ha dicho en la introducción, el corpus de textos escogidos abarca principalmente los años de Basilea (1869-1876) porque es donde existió una producción centrada en lo helénico, ya que las referencias posteriores son más dispersas y con unas circunstancias del pensamiento nietzscheano bien distintas.

Antes de la publicación de El nacimiento de la tragedia, los trabajos de Nietzsche estuvieron centrados en determinar cuáles eran las funciones de los estudios filológicos. En Cómo se llega a ser filólogo (1869), el pensador germano realiza un alegato en favor de un saber más allá de la erudición academicista. Por ejemplo, el estudio de la lengua es sólo un medio para penetrar mejor en los textos antiguos, no necesariamente un fin en sí mismo ${ }^{51}$. La razón de éste y otros ejemplos estriba en que es el amor profundo a lo estudiado lo que debe guiar a la persona ${ }^{52}$. Incluso, ha de buscarse con ahínco el valor universal/filosófico, aquellas enseñanzas que sirven para la vida ${ }^{53}$. Porque en palabras de Nietzsche: «El arte griego es el único que ha superado el condicionamiento de lo nacional.

47. Véase Sánchez Meca, D., "El joven Nietzsche o la paciente búsqueda de lo que es griego", Nietzsche, F., El culto griego a los dioses. Cómo se llega a ser filólogo. Madrid 1999, pp. 13, 17 y 19; Serrano, V., "Introducción", Nietzsche, F., El pensamiento trágico de los griegos. Escritos póstumos 1870-1871. Madrid 2004, p. 15.

48. Gutiérrez Girardot, R., Nietzsche y la... p. 46.

49. Gutiérrez Girardot, R., Nietzsche y la... p. 53.

50. Gutiérrez Girardot, R., Nietzsche y la... p. 76.

51. Nietzsche, F., "Cómo se llega a ser filólogo", Nietzsche, F., El culto griego a... p. 265.

52. Nietzsche, F., "Cómo se llega a ser... p. 267

53. Nietzsche, F., "Cómo se llega a ser... p. 272. 
En él accedemos, ante todo, a lo que es humano, o sea, no al hombre medio, sino a la humanidad más elevada ${ }^{54}$.

En párrafos anteriores se trató la importancia de Homero y la filología clásica para comprender qué entendía Nietzsche por ciencia filológica. Por lo tanto, sería redundante repetir las mismas ideas. Con todo, el texto nos ofrece más cosas. Cuando Silk y Stern hablaban de la noción de «arquetipo» en Nietzsche bien podían referirse a lo siguiente: «Con eso debe quedar manifiesto que toda y cualquier actividad filológica debe estar cercada y albergada por una concepción filosófica del mundo, en la que todo individuo y lo individualizado queda como algo vaporizado y sólo el todo y lo unitario subsiste» ${ }^{55}$.

Con estas palabras, Nietzsche destaca que el valor de todo individuo sólo es posible cuando es capaz de representar el todo, un valor universal o a un pueblo. En el último caso bien podría servir el ejemplo del propio Homero, al que Nietzsche dedica su lección inaugural. El aedo es una personalidad que encarna a todo el pueblo heleno ${ }^{56}$. Pero tal es su universalidad, que ha conseguido ser también un sinónimo de labor poética ${ }^{57}$. Con la imagen de Homero, se entiende bien como para el filósofo alemán una personalidad histórica viene asociada con una serie de ideas o valores, cuestión a recordar cuando se entre específicamente en la cuestión euripidea.

El nacimiento de la tragedia es la obra central sobre el mundo griego escrita por Nietzsche. Conocidas son sus implicaciones biográficas, de desarrollo en el pensamiento nietzscheano o su controvertido valor filológico. Empero, la valoración que aquí se puede hacer del texto es el de que no es algo cerrado. Hay unos precedentes y una revisión que deben ser incluidos en el análisis de la citada obra. Nietzsche sentó las bases de las tesis principales en una serie de conferencias y trabajos inmediatamente anteriores. De todos ellos, se van a destacar tres por su estrecha relación con las tesis nietzscheanas respecto a Eurípides. En primer lugar, en El drama musical griego (1870), hay una crítica a cómo se ha entendido el género trágico. La tragedia no puede ser estudiada mediante un mero acto de erudición ${ }^{58}$. Es un género natural, producto del genio espontáneo de los griegos. A diferencia de lo que opinaban los preceptistas del clasicismo francés, la tragedia no es un género uniforme, sino que su unidad está en la capacidad de expresar lo diverso, es su mayor riqueza ${ }^{59}$. En segundo

54. Nietzsche, F., "Cómo se llega a ser... p. 270.

55. Nietzsche, F., Homero y la Filología clásica. Lección inaugural. Basilea 1869. Madrid 1995, p. 76

56. Nietzsche, F., Homero y la... p. 57.

57. Nietzsche, F., Homero y la... p. 69.

58. Nietzsche, F., "El drama musical griego", Nietzsche, F., El pensamiento trágico de los... pp. 79-80

59. Nietzsche, F., "El drama musical... pp. 96-97. Contrasta esta afirmación con los ataques a Eurípides, precisamente, por no seguir las afirmaciones de lo que debe ser una tragedia 
y tercer lugar, existen dos trabajos sobre el papel de Sócrates en la «muerte de la tragedia», Sócrates y la tragedia (1870) y Sócrates y la tragedia griega (1871). En ellos se enuncia que Eurípides no hizo sino aplicar el ideario socrático ${ }^{60}$. El reemplazo del coro por el diálogo es una de las palmarias innovaciones del trágico, sustituye el equilibrio de un coro que representaba la fuerza interior de lo colectivo (dionisiaco) y la forma individual (apolíneo) por una estructura dialógica que anuncia al diálogo socrático ${ }^{61}$.

Pasando ya a El nacimiento de la tragedia, cuya primera edición venía acompañada de ... a partir del espíritu de la música, es conocida la tesis de lo apolíneo y lo dionisiaco. También se ha mencionado antes la influencia de Schopenhauer en dicha tesis, porque a Dioniso le corresponde la voluntad o lo abstracto, mientras que a Apolo le corresponde la forma representable: «impulsos de la naturaleza humana que los griegos convirtieron en obra humana ${ }^{62}$. A lo largo de toda la obra hay un énfasis en que el equilibrio era necesario para la manifestación de lo trágico, que era imposible reducir lo griego a la mesura apolínea porque el impulso dionisiaco también era imagen de lo helénico ${ }^{63}$. La creación de la tragedia parte de la tensión de lo dionisiaco sobre lo apolíneo y viceversa: "Ambos impulsos, muy diferentes entre sí, siguen un camino parejo, la mayoría de las veces en abierta discrepancia, sin cesar de incitarse mutuamente a generar una escalada de nacimientos cada vez más poderosos y perpetuando a través de ellos ese antagonismo que tan sólo la expresión común «arte» parece mitigar; un antagonismo que impera hasta que, finalmente, en virtud de un milagroso acto metafísico de la "voluntad helénica», aparecen fusionados y mediante esta fusión engendran la obra artística -dionisiaca a la par que apolínea- de la tragedia ática» ${ }^{64}$.

Esta tendencia agonal produce las figuras trágicas. Un modelo explicativo es propuesto por Nietzsche y es el de Prometeo, que en la edición original del texto aparecía en la portada (algo bien significativo) ${ }^{65}$. Por ser un titán, Prometeo representa a fuerzas antiguas y elementales, constituye ello su parte dionisiaca, mientras que al haber sido benefactor de la humanidad es también una presencia apolínea. El ser titán y el haber robado el fuego a los dioses es lo que siembra, justamente, su destino trágico.

\footnotetext{
según la entendió Nietzsche. 149-190.

61. Nietzsche, F., "Sócrates y la tragedia griega... p. 157.

62. Nietzsche, F., El nacimiento de la... p. 28.

63. Nietzsche, F., El nacimiento de la... p. 8.

64. Nietzsche, F., El nacimiento de la... p. 21.

65. Nietzsche, F., El nacimiento de la... pp. 40-41.
}

60. Idea presente en los dos textos: Nietzsche, F., "Sócrates y la tragedia", Nietzsche, F., El pensamiento trágico de los... pp. 99-117; Nietzsche, F., "Sócrates y la tragedia griega"... pp. 
Hay que recordar que, además de las implicaciones filosóficas, la tragedia no deja de ser un género literario y Nietzsche, como filólogo, le presta debida atención. Para él, la poesía en Grecia basculó entre Homero, modelo de artista apolíneo, y Arquíloco, trasunto de artista dionisiaco ${ }^{66}$. Entre la expresión de sueños, de lo popular, lo musical y, en definitiva, de lo espontáneo del último y la progresiva formalización hacia lo prosaico del primero ${ }^{67}$. Mas fue lo trágico lo que sintetizó, mediante la creación de la manera artística más perfecta, ambas maneras de expresión de lo poético. Y tal fue su fuerza que logró poner en sus obras toda una reflexión sobre el significado de la existencia humana:

He aquí el efecto inmediato de la tragedia dionisiaca: el Estado, la sociedad y, en general, todos los abismos que separan a un hombre del otro, ceden terreno ante un poderoso sentimiento de unidad que conduce al mismo corazón de la naturaleza. Ese consuelo metafísico que, como ya se ha sugerido, toda genuina tragedia deja en nosotros, esa idea de que la vida, en el fondo, y pese a toda transformación de sus apariencias, es poderosamente indestructible y placentera; ese consuelo, repito, aparece encarnado con toda nitidez en el coro de sátiros, en cuanto coro de seres naturales cuya existencia, valga la expresión, yace invulnerable bajo toda civilización e inalterable, a pesar de todos los cambios generacionales y de la historia de los pueblos. Es este coro el que brinda consuelo a ese heleno tan especial, profundamente dotado tanto para el sufrimiento más sutil como para el más grave; ese heleno cuya acerada mirada había ya penetrado en la terrible tendencia destructiva de la Ilamada Historia Universal, así como en la crueldad de la naturaleza hasta el punto de correr el riesgo de anhelar la negación budista de la voluntad. A éste lo salvará el arte, y a través del arte será la vida quien lo salve... para sí misma ${ }^{68}$.

Ante este evocador sentido, que Nietzsche ofrece al lector, son comprensibles los ataques furibundos a aquellos que él cree causantes de la destrucción de una de las cimas creativas helénicas. Es aquí, cuando se introduce el concepto de «muerte de la tragedia» y entra en escena Eurípides. De él, este trabajo se ocupará luego. Si vamos a Sócrates, el instigador principal según Nietzsche, se volvería a la idea del principio: Eurípides es sólo una «máscara» porque es Sócrates quién inspiró al trágico a realizar un proceso de racionalización y casi de historización del género. Sócrates es el introductor de la llamada "cultura teórica», que en el mundo helenístico o "alejandrino», como lo

66. Nietzsche, F., El nacimiento de la... pp. 2, 43.

67. Nietzsche, F., El nacimiento de la... pp. 45-52.

68. Nietzsche, F., El nacimiento de la... p. 58. 
denomina Nietzsche, alcanza su culminación. Es el final del mito, que había posibilitado ese ser poético en los griegos:

De hecho, un pueblo -como también, por otra parte, un hombrees tanto más valioso cuanto más capaz es de imprimir en sus vivencias el sello de lo eterno: entonces queda, por así decirlo, desmundanizado y muestra su profunda e inconsciente convicción de la relatividad del tiempo y del significado verdadero, esto es, metafísico, de la vida. Lo contrario sucede cuando un pueblo comienza a comprenderse en términos históricos y a demoler en derredor los baluartes míticos: este proceso suele ser acompañado de una mundanización radical, una ruptura con la metafísica inconsciente de su existencia anterior y con todas sus consecuencias éticas. El arte griego y, en particular la tragedia griega, retardaron la destrucción del mito ${ }^{69}$.

La entrada en la historia y la razón acabaron con la poesía y el mito. Pero ante lo que parece una cuestión de cambio cultural ha de volverse, de nuevo, a lo filosófico, que es objeto de una revisión posterior por parte del filósofo alemán. Para empezar, hubo un cambio de título en la edición de 1874, pasándose a subtitularse ... helenismo y pesimismo; esto no es simplemente por el final de la amistad con Wagner sino también por la creciente orientación de un Nietzsche más filósofo que filólogo. De hecho, en 1886, publicó un Ensayo de autocrítica como nuevo prólogo a la obra ${ }^{70}$. En él, se realizó una explicación de cómo la obra, llevada hasta sus últimas consecuencias, debía estar asentada sobre el sentido de pesimismo ${ }^{71}$. A esto cabe recordar cómo Kierkegaard comparó el pesimismo de los antiguos con el de los modernos. Sin embargo, Nietzsche fue profundamente crítico con lo que había escrito pues, a su juicio, debido al estilo y a cierto compromiso con su labor como filólogo, la obra no llegó hasta donde debió, no dijo todo lo que tenía que decir ${ }^{72}$.

Paralelamente a la redacción de El nacimiento de la tragedia, Nietzsche compuso dos interesantes trabajos que pueden complementar bien lo que pensaba sobre el mundo griego mientras, como se ha dicho, escribía una de sus obras magnas. En El Estado griego (1871) y en La lucha de Homero (1872) se habla sobre lo positivo del valor aristocrático y sobre la posibilidad en la Grecia presocrática del genio, incluso en la democracia ateniense. Un claro contraste con la época contemporánea: «En el mundo moderno, que en comparación con el mundo griego no produce casi más que monstruos y centauros, y en el cual

69. Nietzsche, F., El nacimiento de la... p. 147.

70. Conviene leerlo: Nietzsche, F., "Ensayo de autocrítica", Nietzsche, F., El nacimiento de la... pp. 3-17.

71. Véase Nietzsche, F., "Ensayo de... pp. 4-5, 10.

72. Nietzsche, F., "Ensayo de... p. 13. 
el hombre individual, como aquel extraño compuesto de que nos habla Horacio al empezar su "Arte Poética", está hecho de fragmentos incoherentes, comprobamos a veces, en un mismo individuo, el instinto de la lucha por la existencia y la necesidad del arte ${ }^{73}$.

En Grecia fue posible el genio porque el hombre que dominaba socialmente a otros era aceptado ${ }^{74}$. Incluso la resistencia, con métodos como el ostracismo, sólo estaba para permitir a otros competir y ascender ${ }^{75}$. Este contexto tan favorable no podía dejar de ser feraz para el genio creador, artístico finalmente ${ }^{76}$. Un Sófocles magistrado y trágico a la vez.

Asimismo, completan lo enunciado en El nacimiento de la tragedia una serie de trabajos posteriores a ésta. El primero de ellos, La filosofía en la época trágica de los griegos (1873), ofrece una idea de la pureza y maravillosa creatividad del pensamiento heleno antes de Sócrates y Platón. La filosofía, como se puede ver en los relatos del origen del mundo de Tales de Mileto, no estaba reñida con el mito ${ }^{77}$. Antes bien, era consecuente con el significado último del mito: la vida como devenir y contradicción, que Heráclito tan bien expuso ${ }^{78}$. Claro es el contraste con la labor de Sócrates, expuestas en un texto posterior (1876) y donde vuelve a ideas ya enunciadas de un Sócrates "plebeyo» que abjuró de la cultura mítico-trágica y corrompió a las nuevas generaciones con sus ideas racionalistas y moralistas ${ }^{79}$.

Tremendamente fundamentales son una serie de apuntes sobre la historia de la literatura griega (1874-1876) porque muestran una interpretación global del hecho literario en la antigua Grecia, una perspectiva evolutiva ${ }^{80}$. De ellos,

73. Nietzsche, F., "El Estado griego. Prólogo a un libro que no se ha escrito", Nietzsche, F., Obras completas. Vol. V. Buenos Aires 1963, p. 114.

74. «La inmensa mayoría de los individuos debe ponerse al servicio de una minoría. Esta mayoría debe ser esclavizada, subordinando sus necesidades individuales a fines más altos. A su costa, por su ímprobo trabajo, aquella clase privilegiada se sustrae a la lucha por la existencia para engendrar y dar cima a un nuevo mundo y a nuevas necesidades». En Nietzsche, F., "El Estado griego... p. 116.

75. «Esta es la esencia de la idea helénica de la lucha: aborrece la hegemonía de uno solo y teme sus peligros; quiere albergar como "medio de protección" contra el genio, un segundo genio». En Nietzsche, F., "La lucha de Homero. Prólogo para un libro que no se ha escrito", Nietzsche, F., Obras... p. 135.

76. «El hombre, como en sus más nobles y elevadas funciones, es siempre una parte de la Naturaleza y ostenta el doble carácter siniestro de aquella. Sus cualidades terribles, consideradas generalmente como inhumanas, son quizá el más fecundo terreno en el que crecen todos aquellos impulsos, hechos y obras que componen lo que llamamos Humanidad». En Nietzsche, F., "La lucha de... p. 132.

77. Nietzsche, F., La filosofía en la época trágica de los griegos. Madrid 1999, p. 50.

78. Nietzsche, F., La filosofía en la... pp. 67-68.

79. Nietzsche, F., La filosofía en la... pp. 185-186, 193.

80. Nietzsche, F., "Historia de la literatura griega". Partes I, II y III, Nietzsche, F., Obras... pp. 277-376. 
se hablará más en profundidad en relación a Eurípides. No obstante, una idea con la que hay que quedarse es la noción del surgimiento de lo "clásico»: cuando la creación artística pasa de ser un acto de espontaneidad a ser un producto de la lectura de lo precedente, lo anterior es lo que se convierte en «clásico» ${ }^{81}$.

Por último, quedaría El culto griego a los dioses (1875-1876), en el que se expone la base religiosa que hay detrás de la creación artística del pueblo griego: "Su "literatura clásica" con el canon del coro, la tragedia, la comedia, ha crecido incluso en gran medida sobre el suelo del culto o como una prolongación de éste. Se podría preguntar, entonces, si una época como la nuestra, que tiene su fortaleza en las máquinas y en el desarrollo de la guerra, emplea su fuerza de una forma absolutamente más útil $\aleph^{82}$. Es más, la síntesis trágica hubiera sido imposible sin un hecho religioso que era capaz de aunar los plurales impulsos helénicos (poleis, los individuos, las tradiciones foráneas...) con un sistema sancionador y que permitía cohesionar a la comunidad ${ }^{83}$. Contenido y forma, Dioniso y Apolo.

Llegados a este punto, al lector le puede parecer superfluo e incluso conocidas muchas de las cosas expuestas en esta larga digresión sobre Nietzsche y el mundo griego. Posiblemente así sea, pero la intención de estas líneas está al servicio de una mejor comprensión de lo que pudo significar la figura de Eurípides para el pensador germano. Nietzsche respondía a una tradición recibida, a un profundo sentir de lo griego por el alemán, y, a la vez, éste fue un hito en dicha recepción de lo helénico. Sabido esto, visto la importancia de lo mítico en contraste con la racionalización posterior, podemos penetrar ya en el agón, la lucha entre el trágico y el filósofo.

\section{Eurípides en la obra de Nietzsche}

De la variada obra nietzscheana sobre el mundo griego hay una serie de textos donde aparece Eurípides. En este apartado se van a recoger las principales ideas que Nietzsche expresó en relación al trágico. Y, sin lugar a dudas, es en EI nacimiento de la tragedia donde el personaje está más abundantemente retratado. Pero, antes de llegar a ella, no se pueden olvidar los trabajos preparatorios de ésta. En Sócrates y la tragedia se expone a un Eurípides como ejecutor de las ideas socráticas. Sirvan de recuerdo las siguientes líneas: «En Eurípides se da por el contrario una luminosidad contenida, propia de los artistas modernos: su carácter artístico casi no griego se puede concebir del modo más sintético bajo el concepto de socratismo, «todo ha de ser consciente para ser bello» es el prin-

81. Nietzsche, F., "Historia de la literatura griega. Parte III... pp. 342, 347.

82. Nietzsche, F., El culto griego... p. 52.

83. Nietzsche, F., El culto griego... pp. 57, 74. 
cipio de Eurípides paralelo al socrático «todo ha de ser sabido para ser bueno». Eurípides es el poeta del racionalismo socrático» ${ }^{84}$.

El trágico y su arte representaban una novedad radical porque «Eurípides fue un pensador solitario, desde luego no un pensador según el gusto de la masa entonces dominante, en la que despertaba escrúpulos como personaje original desabrido» ${ }^{85}$. Es el primero que sigue una "estética consciente» la cual tiene varias características como son un arte retórico, un lenguaje inspirado en la realidad y no en lo mítico e incluso un intenso naturalismo ${ }^{86}$.

Respecto al Eurípides de El nacimiento de la tragedia, se van a tratar dos puntos. Por un lado, está la cuestión de cómo Nietzsche caracteriza al trágico: ciertamente como antitrágico. Eurípides es más un sofista que un poeta:

De este modo el Eurípides de Aristófanes presumía como honor suyo haber representado la vida común, familiar, cotidiana, sobre la que cualquiera tenía capacidad de emitir un juicio. Si a partir de este momento la amplia masa se entrega a la filosofía y, con una perspicacia sin parangón, administra sus tierras y bienes, y conduce sus procesos, no cabe duda de que el mérito es suyo, el resultado de alguien que ha inculcado con éxito la sabiduría al pueblo ${ }^{87}$.

Además de lo dicho, una idea sustancial son las fuentes que el autor cita para construir la imagen del personaje. En el fragmento anterior se cita a Aristófanes, pero anteriormente ya se habló también de Diógenes Laercio. Nietzsche es dependiente de una serie de fuentes primarias sobre Eurípides, o al menos están escogidas premeditadamente ${ }^{88}$. Con ellas se crea un Eurípides educador de la masa, aunque contradictoriamente no puede dejar de despreciarla y sentirse despreciado por ella. También, de dichas fuentes, proviene la idea de un Eurípides sacrílego ${ }^{89}$.

En cualquier caso, la idea fundamental que subyace en la caracterización del Eurípides nietzscheano es su inseparable unión con Sócrates:

Como poeta, Eurípides - he aquí la solución del enigma planteadose sentía ciertamente un ser superior a la masa, pero no a dos de sus espectadores; Ilevó a la masa al escenario, más veneró a estos dos espectadores como si fueran los únicos jueces y maestros capaces de justipreciar todo su arte. Siguiendo sus directrices y advertencias, transfirió a las

84. "Sócrates y la tragedia... p. 107.

85. "Sócrates y la tragedia... p 104.

86. "Sócrates y la tragedia... pp. 106, 101; Nietzsche, F., "Sócrates y la tragedia griega... p. 173.

87. Nietzsche, F., El nacimiento de la... p. 80.

88. Véase también Nietzsche, F., El nacimiento de la... p. 90.

89. Nietzsche, F., El nacimiento de la... p. 77. 
almas de sus héroes sobre el escenario todo el mundo de sentimientos, pasiones y experiencias que hasta ahora, a modo de un coro invisible, había ocupado el lugar de las gradas destinadas a los espectadores en toda representación solemne; obedeció a sus exigencias cuando buscaba para estos nuevos personajes hasta nuevas palabras y tonos, y únicamente en sus voces oyó los veredictos legítimos respecto a su acción creadora, o las alentadoras promesas de victoria cuando alguna vez que otra se veía condenado por el tribunal del público ${ }^{90}$.

La idea del doble espectador es la que mejor introduce qué era el binomio Eurípides-Sócrates. Si el primero era el propio Eurípides, que puso a su propio servicio la creación poética, el segundo vendría dado por el siguiente contexto:

Fue en esta situación atormentada cuando Eurípides se topó con el segundo espectador que no comprendía la tragedia y por esta razón tampoco la apreciaba. Gracias a esta alianza, pudo atreverse a liberarse de su aislamiento y a iniciar una enorme batalla contra las obras de Esquilo y Sófocles: no bajo una forma panfletaria, sino en calidad de poeta dramático que oponía su idea de tragedia a la tradicional ${ }^{91}$.

Este segundo espectador, que no es otro sino Sócrates, le da a la tragedia euripidea su carácter, su consecuencia última: «(...) eliminar de la tragedia ese poderoso elemento originario y todopoderoso, y reconstruirla sobre la nueva y purificada base de un arte, una moral y una concepción del mundo no dionisiaca» ${ }^{92}$. Convirtiendo a Eurípides en el "poeta del socratismo estético» ${ }^{93}$.

Por otro lado, existe una reflexión nietzscheana sobre la producción euripidea. Para el filósofo, el tema central es el final del mito. El final, particularmente hablando, de Dioniso. Hasta entonces, el dios había sido el protagonista de todas las tragedias, enmascarado en personajes sufridores (semejante al sufrimiento del dios) tales como Edipo o Prometeo ${ }^{94}$. La tragedia no dejaba de ser la forma las elevada del mito y por eso la creación de Eurípides supuso una ruptura de raíz. Al no creer en el mito, Eurípides se empeña en acabar con él:

¿Qué intención abrigabas, sacrílego Eurípides, cuando intentaste obligar a este moribundo a que, una vez más, se pusiera a tu servicio? Él murió bajo tus brutales manos; y ahora necesitabas un mito de imitación, un mito enmascarado, igual que ese mono de Heracles, que sólo sabía

\footnotetext{
90. Nietzsche, F., El nacimiento de la... p. 82.

91. Nietzsche, F., El nacimiento de la... p. 83.

92. Nietzsche, F., El nacimiento de la... p. 84.

93. Nietzsche, F., El nacimiento de la... p. 89.

94. Nietzsche, F., El nacimiento de la... p. 74.
} 
engalanarse con los atavíos pomposos de tiempos pasados. Cuando se te murió el mito también se te murió el genio de la música. Por mucho que tus ávidas manos desvalijaran todos los jardines de la música, no obtuviste más que una imitación de mascarada musical. Al abandonar a Dioniso te abandonó también Apolo. Ahuyenta a todas las pasiones guarnecidas en sus guaridas y enciérralas dentro de tus dominios, cuida de acelerar y pulir una dialéctica sofística a la altura de los discursos de tus héroes... Pues también tus héroes no disponen más que de pasiones simuladas y como de mascarada, y no profieren más que discursos simulados y enmascarados ${ }^{95}$.

Para acometer semejante labor, Eurípides se sirvió de una serie de técnicas y métodos que convergieron dando lugar a algo completamente antitrágico. Un primer ejemplo sería la eliminación del coro, la masa desaparece y entra a la vez. Desaparece como pasión colectiva y entra como individuo en el diálogo:

Gracias a él el hombre de la vida cotidiana salió de los graderíos del escenario: el espejo en el que antaño no encontrábamos expresión más que de rasgos de grandeza e intrepidez, ahora reflejaba esa embarazosa fidelidad que reproduce escrupulosamente hasta las líneas deformes pergeñadas por la naturaleza ${ }^{96}$.

Introducir al espectador también vino, de acuerdo con Nietzsche, a degenerar lo discursivo. En su nivel dionisiaco todo acabó en mero sentimentalismo, en su nivel apolíneo todo se redujo a falsa épica ${ }^{97}$. El nuevo discurso se construye mediante el método socrático de hacer las cosas inteligibles, lo racionaliza todo y manipula las palabras mediante el arte retórico ${ }^{98}$. El personaje-tipo es uno de los ejemplos de lo que se acaba de decir. En un mundo tan teórico como el euripideo-socrático, los personajes están para explicar algo mediante unas formas que convergen en un ser identificable ${ }^{99}$. Otro caso es el Deus ex machina, o resolución artificial del conflicto en lugar del «consuelo metafísico» de la resolución natural del conflicto ${ }^{100}$. Tanta artificiosidad no es sino la consecuencia final de un «arte consciente» que busca controlarlo todo explicándolo todo ${ }^{101}$.

Todos estos elementos son importantes porque tuvieron herederos, Eurípides ejerció una influencia corruptora sobre la creación posterior. Al tener conti-

95. Nietzsche, F., El nacimiento de la... p. 77.

96. Nietzsche, F., El nacimiento de la... p. 79.

97. Nietzsche, F., El nacimiento de la... p. 86.

98. Nietzsche, F., El nacimiento de la... p. 87.

99. Nietzsche, F., El nacimiento de la... p. 113.

100. Nietzsche, F., El nacimiento de la... p. 114

101. Nietzsche, F., El nacimiento de la... p. 88. 
nuadores, por ejemplo, en la Comedia Nueva, Eurípides acabó sentenciado de muerte al género trágico ${ }^{102}$.

Una fuente interesante, que no suele ser tenida en cuenta a la hora de describir los alegatos de Nietzsche en contra de Eurípides, son sus lecciones sobre historia de la literatura griega, las cuales muestran una contextualización más sistemática y unos juicios no tan rabiosamente radicales. En ellos, la tragedia representa el último triunfo del mito, del sentido de comunidad helena y de la universalidad del destino del hombre ${ }^{103}$. Eurípides es lo contrario, es lo histórico y racionalizado. Su arte depende tanto de él como individuo como de la época en la que le tocó vivir. Si se atiende a lo primero, podemos definir la Atenas de la segunda mitad del siglo $\mathrm{V}$ a. C. como un período de desconfianza hacia lo mítico. Para Eurípides, al perder su significado previo, lo mítico sólo era la «tramoya dramática» o el escenario del que se servía para situar sus historias ${ }^{104}$. Por otra parte, Eurípides, en contraposición con Esquilo o incluso Aristófanes, refleja la lucha habida en la polis entre el aristocratismo y el democratismo ${ }^{105}$. Todo esto a pesar del aparente apoliticismo del trágico ${ }^{106}$. ¿Aunque no es lo apolítico finalmente una expresión de la mediocridad de la clase media? En cualquier caso, sus continuadores recogieron el legado de sátira a todo lo tradicional ${ }^{107}$.

Como individuo, Eurípides es uno de los primeros griegos eruditos y también uno de los responsables de la creación de lo «clásico». ¿De dónde surge la imitación en Eurípides? Bien de la sacralización, bien de la crítica a lo ya hecho. La principal característica de lo «clásico» es su labor formativa. La literatura ya no es creada libremente, sino que se somete a la lectura, se ve esclavizada bajo lo canónico ${ }^{108}$. El pensamiento simbólico-metafísico precede al causal y deductivo. La extraordinaria satisfacción sentida por los griegos cuando hubieron hecho de su idioma un instrumento severo, dúctil y lógico, penetra el pueblo entero, y la masa lo siente lo mismo en Eurípides que en los filósofos. Con ello aumenta el valor de la escritura. Eurípides es el primer gran lector entre los autores literarios, y posee una biblioteca propia ${ }^{109}$.

Es un cambio total de paradigma de lo que debe ser el acto creador. Preocupados por las minucias, los herederos de Eurípides que Ilegan hasta la misma Modernidad, se dirigen al espectador concreto, al que ha leído lo mismo que ellos ${ }^{110}$. Lo universal ha llegado a su fin.

102. Nietzsche, F., El nacimiento de la... p. 78.

103. Nietzsche, F., "Historia de la literatura griega. Partes I y II... pp. 297-298.

104. Nietzsche, F., "Historia de la literatura griega. Partes I y... p. 301.

105. Nietzsche, F., "Historia de la literatura griega. Partes I y... p. 306.

106. Nietzsche, F., "Historia de la literatura griega. Partes I y... pp. 300-301.

107. Nietzsche, F., "Historia de la literatura griega. Partes I y... p. 309.

108. Nietzsche, F., "Historia de la literatura griega. Parte III... p. 342.

109. Nietzsche, F., "Historia de la literatura griega. Parte III... p. 347.

110. Nietzsche, F., "Historia de la literatura griega. Parte III... p. 344. 


\section{Sentido y originalidad del Eurípides nietzscheano}

Como se ha repetido tantas veces en este trabajo, la idea más evidente en Nietzsche respecto a Eurípides es que este último fue el causante de la «muerte de la tragedia» a nivel artístico. Prácticamente toda la investigación ha puesto el foco en este punto, tanto para afirmarlo como para negarlo. Todos ven en el Eurípides nietzscheano un síntoma de los nuevos tiempos. En palabras de Esteban Enguita: «Eurípides, más que el portavoz de Sócrates, era el portavoz de los «nuevos tiempos», un perspicaz observador que elabora poéticamente la mentalidad, los problemas y las aspiraciones de los ciudadanos atenienses y que les educa -no se puede olvidar la función educativa y formadora de teatro dentro de la tradición ateniense- para responder a las exigencias de la nueva realidad social y política de Atenas ${ }^{111}$.

Rafael Angel Herra, en su artículo, explica cómo Nietzsche liga a Eurípides con la disolución de lo mítico y el auge del racionalismo: «Pero vemos aquí que a Nietzsche parece preocuparle, con la aparición de Eurípides, más la muerte de la poesía que la de la tragedia misma -el originario sentido de la tierra y del dolor-; le molesta la desaparición de una estética que él prefiere, pero no acentúa con profundidad el cambio inconmensurable de toda la historia espiritual del pueblo griego. La disolución de la tragedia puede verse como la afloración exterior de la raigambre ínsita de este cambio brusco y definitivo que Jaeger Ilamó la agonía de Grecia» ${ }^{112}$. Para el autor del fragmento, la tragedia había retrasado el final del pensamiento mítico convirtiendo a éste en arte, pero el difícil equilibrio entre lo dionisiaco y lo apolíneo se acabó rompiendo produciéndose la inevitable secularización ${ }^{113}$.

La tesis del papel de Eurípides en el cambio cultural mencionado no es propiamente original de Nietzsche, aunque el impacto de éste ha sido mayor que el de otros. Fue el Romanticismo alemán el que elaboró una teoría de la poética griega en la que Eurípides no salía bien parado. Tal y como se pudo ver en el apartado sobre Nietzsche y lo griego, el magisterio de los hermanos Schlegel fue determinante para el filósofo alemán. Friedrich Schlegel fue el creador de la imagen de Eurípides durante buena parte del siglo XIX. Para él, Eurípides era el genio de la desmesura, pero también el que más intentó acercar la poesía a la filosofía ${ }^{114}$. La principal conclusión a la que llegó el menor de los Schlegel fue que Eurípides, en su singularidad, no conectó con un género basado en la tradición de lo colectivo ${ }^{115}$. Sus tragedias no eran verdaderas. August W. Schlegel ahondó en lo dicho por su hermano y directamente acusó a Eurípides de acabar

111. Esteban Enguita, J. E., El joven Nietzsche... p. 122.

112. Herra, R. A., "La disonancia hecha carne... p. 40.

113. Herra, R. A., "La disonancia hecha carne... p. 40.

114. Schlegel, F., On the Study of... p. 351.

115. Schlegel, F., On the Study of... pp. 72-74. 
con tragedia ${ }^{116}$. Los argumentos son conocidos y, en cierta medida, iguales a los de Nietzsche. Eurípides abandonó el fondo religioso-metafísico de la tragedia, eliminando la idea de destino e interpretando alegóricamente los mitos ${ }^{117}$.

La tradición romántica ha tenido sus continuadores después de Nietzsche. George Steiner en La muerte de la tragedia abona la idea de que, en toda época de esplendor cultural, el teatro es el género más vivo ${ }^{118}$. Los tiempos modernos, con la pérdida del sentido mitológico del mundo, no pueden generar un buen arte dramático: «la decadencia de la tragedia está indisolublemente asociada a la decadencia de la cosmovisión orgánica y su consiguiente contexto de referencia mitológica, simbólica y ritual» ${ }^{119}$. El cristianismo o el marxismo son, para Steiner, totalmente antitrágicos y no pueden ofrecer el material que los dioses y héroes paganos otorgaron a lo trágico ${ }^{120}$.

Incluso dentro del campo de la filología, hay autores que han defendido, como Nietzsche, que Eurípides supuso un cambio. Rodríguez Adrados puede ser un buen ejemplo de ello. De una moral aristocrática, pero a la vez colectiva, se pasa a una moral individual, aunque a la vez encarnada en el hombre común ${ }^{121}$. Eurípides realizó innovaciones en este sentido, siendo uno de los «inventores» del amor pasional individual ${ }^{122}$.

Sin embargo, no todos los estudiosos están de acuerdo con la tesis de Nietzsche, al menos en sus implicaciones más genéricas. Como primer ejemplo, están las palabras de Silk y Stern:

La medida de la injusticia para el Eurípides de Nietzsche es su afirmación de que Eurípides mató a la tragedia. La repetida subversión de las normas tradicionales por un genio revolucionario, indudablemente, hizo difícil para sus sucesores volver a la tradición o (por falta de su genio) llevar sus innovaciones mucho más lejos, pero Eurípides es un síntoma de crisis, más que su causa. Hubo, como hemos visto, fuerzas mucho más grandes trabajando. Tampoco Eurípides es el único elemento subversivo de la tradición, el "tradicionalista" Aristófanes es otro para quien las antiguas normas generales han perdido claramente parte de su significado. Nietzsche concede que Eurípides no es el inventor de su espíritu "socrático", pero aún le atribuye demasiada culpa ${ }^{123}$.

116. Behler, E., "A. W. Schlegel and the... p. 354.

117. Behler, E., "A. W. Schlegel and the... pp. 357-358.

118. Steiner, G., La muerte de la tragedia. Barcelona 2001, p. 183.

119. Steiner, G., La muerte de... p. 214.

120. Steiner, G., La muerte de... p. 237.

121. Rodríguez Adrados, F., La Democracia ateniense. Madrid 1985, pp. 36, 341-343.

122. Rodríguez Adrados, F., El mundo de la lírica griega antigua. Madrid 1981, p. 58.

123. Silk, M. S. y Stern, J. P., Nietzsche on... p. 262. 
Para ciertos autores, existen en Nietzsche multitud de inexactitudes, juicios morales extemporáneos y numerosas contradicciones. ¿Qué Eurípides está representando Nietzsche? ¿Se ajusta algo a la realidad histórica? No son preguntas nuevas. Wilamowitz ya basó parte de su crítica a El nacimiento de la tragedia en desacreditar las afirmaciones nietzscheanas sobre el trágico griego. Para el filólogo, la obra euripidea tenía una belleza distinta, no era una degeneración de un modelo ideal ${ }^{124}$. Era un buen autor trágico porque representó en el escenario el sufrimiento humano y utilizó ampliamente el material proporcionado por los relatos míticos ${ }^{125}$.

Pero es que, además, para Wilamowitz, hubo en Nietzsche un serio problema de fuentes. No hubo una verdadera relación entre Eurípides y Sócrates, contrariamente a lo que Nietzsche repitió una y otra vez. Únicamente Aristófanes cita dicha relación, Jenofonte y Platón no dijeron nada al respecto; por no hablar de que Eurípides compuso obras bastante antes de la entrada en la escena pública de Sócrates ${ }^{126}$.

Aristófanes, como fuente principal para Nietzsche, ha sido tratado por varios académicos. Siguiendo a Donald J. Mastronarde:

La representación de Aristófanes es la fuente más temprana de la idea de que en Eurípides, en contraste con Esquilo, la astucia retórica, el vestuario "realista", la elección del mito sensacionalista y el estilo lírico innovador disminuyen la dignidad del género trágico y fracasan en proporcionar edificación para la audiencia; así como también la idea de que Eurípides es ateo ${ }^{127}$.

Otros, como Kaufmann, han preferido criticar directamente el mismo fundamento filosófico nietzscheano por poner a Sócrates como el adversario. ¿Y por qué no Platón? ${ }^{128}$ ¿No fue el que atacó en La República a la poesía trágica? Además de que Eurípides tenía su propia autonomía artística, como todos los autores helenos la tuvieron:

Lo que ahora nos interesa es que Eurípides no tenía por qué recoger esas historias, y mucho menos tenía que manejarlas tal como lo hizo. Él quiso comunicar ciertos sentimientos, pensamientos y actitudes, y buscó

124. Wilamowitz, U. von, “FFilología del... p. 70.

125. «Esto explica por sí mismo que para él las aspiraciones y equivocaciones de la humanidad, sus errores y arrepentimientos, aparecieran como algo sin esperanza y sin consuelo». En Wilamowitz, U. von, “FFilología del... p. 91. Sobre los mitos, véase Wilamowitz, U. von, “¡Filología del... p. 92.

126. Wilamowitz, U. von, “¡Filología del... pp. 89-90.

127. Mastronarde, D. J., The Art of Euripides. Dramatic Technique and Social Context. Cambridge/New York 2011, p. 2.

128. Kaufmann, W., Tragedia... pp. 28-63. 
el mito adecuado a sus propósitos. Lo que necesitaba era una acción simbólica para despertar las respuestas deseadas ${ }^{129}$.

Para Henrichs, el problema de las fuentes en Nietzsche se basa en que no son de primera mano. Por un lado, sigue bastante al pie de la letra las tesis de los hermanos Schlegel y la cuestión de la conexión socrática en Eurípides ${ }^{130}$. Pero es que, por otro lado, no se puede estar seguro de que el propio Eurípides fuera una de las lecturas principales que el pensador germano tuvo en cuenta para elaborar sus juicios sobre éste.

Su tratamiento de Eurípides sugiere que apenas había leído al autor de quien era tan crítico y que conocimientos tan limitados como los que él tenía eran en su mayor parte de segunda mano y derivados de Schlegel, de cuyas conferencias de Viena había Nietzsche tomado notas en el otoño de $1869^{131}$.

Finalmente, surge la pregunta: si el Eurípides nietzscheano no puede ser un personaje histórico, ¿cómo hay que interpretarlo? En la noción de «máscara» puede estar la respuesta. Hay un enmascaramiento. Nietzsche no es totalmente sincero respecto a Eurípides. Son Las bacantes donde mejor se puede observar el trampantojo nietzscheano. Esta obra es una de las principales fuentes para conocer el culto dionisiaco. Para Robert Graves su valor está en ser una de las primeras, anterior a Teócrito u Ovidio ${ }^{132}$. Mircea Eliade lo califica sin ambages como «el documento más importante» ${ }^{133}$. Henrichs expone que:

Como el profeta de una nueva "visión dionisíaca del mundo", Nietzsche no podía permitirse ignorar una obra cuyo tema estaba tan relacionado con su teoría de la tragedia, aunque su autor fuera Eurípides. La fuerte discrepancia entre la poderosa representación de Dionisio, del estado de ánimo dionisíaco en Las bacamtes y la supuesta "tendencia no dionisíaca" (BT 12) de la tragedia de Eurípides en general, debería haber sido un grave obstáculo para Nietzsche. Pero lejos de eso, con un aplomo casi imprudente, se deshace del obstáculo potencial en una sola página, una de las menos gratificantes de todo el ensayo. Como lo ve Nietzsche, el campeón de toda la vida del racionalismo absoluto había perdido finalmente la confianza en el poder de la razón, hizo las paces con Dionisio, y escribió Las bacantes como una retractación ("Widerruf") $)^{134}$.

129. Kaufmann, W., Tragedia... p. 139.

130. Henrichs, A., "The Last of the Detractors... pp. 370-375.

131. Henrichs, A., "The Last of the Detractors... p. 382.

132. Graves, R., Los mitos griegos. Vol. 1. Madrid 2011, p. 154.

133. Eliade, M., Historia de las creencias y de las ideas religiosas. Vol. I. Madrid 1978, p. 380.

134. Henrichs, A., "The Last of the Detractors... p. 391. 
Semejante revelación nos lleva a buscar una explicación en el estilo de escritura de Nietzsche, que puede ser entendido como retórica, como una ficción discursiva. Según Fink, el estilo nietzscheano busca provocar en el lector una "excitación estética», aún a costa de encubrir ciertas cosas ${ }^{135}$. El efecto es lo importante, no tanto el contenido. Después de haber achacado a Eurípides el ser retórico, una sonrisa irónica puede nacer de esta conclusión. La solución a todo este enigma la pone Michael Hinden: «Sin embargo, al final, debemos recordar que la voz que habló más fuerte en Eurípides no era un dios o un crítico, sino una voz de dramaturgo, controvertida e irascible. Cuando recordamos esto, nos sorprende nuevamente el motivo de Nietzsche al desatar tanta amargura contra el poeta. Después de todo, ipor qué elegir pelear con los muertos a menos que exista una analogía amenazante? Con esta pregunta volvemos a nuestro punto de partida. Debajo de su ira (que de hecho era una pose retórica), Nietzsche pudo haber sentido un parentesco agonizante con Eurípides. Al menos, parece poco probable que el paralelismo se le escape. Eurípides el escéptico apasionado, el trágico irónico, fue para sus modelos Sófocles y Esquilo lo que Nietzsche fue para Schopenhauer, Hegel, Kant, sus mentores en filosofía. Otra era estaba llegando a su fin ${ }^{136}$. Nietzsche es el propio Eurípides, pero usa la máscara del agón para ocultar lo que quizás el filósofo vio como una excesiva dependencia. Volviendo a las mismísimas fuentes nietzscheanas se puede comprender mejor esto.

En El nacimiento de la tragedia se pasa, sin transición alguna, de citar en una página a Las bacantes como una fuente para lo que se está enunciando sobre Dioniso, para en páginas posteriores dedicarse a demoler a su autor ${ }^{137}$. La solución retórica la encontramos en las siguientes palabras: «Por mucho que tratara de consolarnos Eurípides con su retractación, no tendrá éxito: el soberbio templo yace en medio de las ruinas. ¿De qué nos sirve el lamento del destructor o su confesión de que éste era el más bello de todos los templos? ¿A quién podría satisfacer la pobre compensación de que el tribunal artístico de la posteridad haya condenado al propio Eurípides a transformarse en dragón?»138 Las bacantes es el arrepentimiento final de Eurípides, a tenor de lo que Nietzsche dice. Según Janz, este tipo de ambigüedades, juegos de palabras, silencios, o construcciones retóricas responden a que $\mathrm{El}$ nacimiento de la tragedia es más un «libro confesional» que un trabajo filológico ${ }^{139}$. Tampoco es que Nietzsche estuviera plenamente contento con el estilo escogido, como se pudo ver en su ensayo autocrítico.

135. Fink, E., La filosofía de... p. 14.

136. Hinden, M., "Nietzsche's Quarrel... p. 260.

137. Sobre la referencia a Las bacantes, véase Nietzsche, F., El nacimiento de la... p. 45.

138. Nietzsche, F., El nacimiento de la... p. 85.

139. Janz, C. P., Friedrich Nietzsche. Vol. II. Los diez años de Basilea (1869-1876). Madrid 1981, p. 131. 
Sin embargo, la idea de confesionalidad inspira otra: la de paralelismo vital. En las lecciones sobre literatura griega se pueden encontrar algunos. Por ejemplo, la idea de impopularidad o incomprensión (recordemos que son posteriores al «escándalo» de la publicación de El nacimiento de la tragedia) está presente tanto en Eurípides como en Nietzsche; ambos se alejan progresivamente de lo público, de la política ${ }^{140}$. Para Albin Lesky, Eurípides es uno de los primeros casos de genio aislado ${ }^{141}$. Además, hay que recordar que tanto Eurípides como Nietzsche contemplan el pasado, obras geniales de sus antecesores. Ambos son lectores de lo "clásico». Ambos crean a partir de lo que otros han hecho, aunque también sufren la «ansiedad» de saberse deudores, de no ser genios únicos.

Por todas estas razones, la relación de Nietzsche con Eurípides es totalmente agonal. Pero también es, el trágico heleno, la máscara de la que se sirve Nietzsche para ejemplificar las consecuencias de ciertas derivaciones del arte y el pensamiento modernos. Vicente Serrano afirma que «Cabría decir que estamos implícitamente ante una teoría de la modernidad, si bien esbozada en el campo ideal de una disimulada concepción de lo griego» ${ }^{142}$. Eurípides simboliza el triunfo de la prosa frente a la poesía y también el de la ciencia racional frente a la irracionalidad mítico-trágica. Eurípides/Sócrates unen lo artístico y lo filosófico, algo que en Nietzsche es totalmente indisociable.

Las máscaras, los arquetipos, los personajes-idea son una característica del pensamiento nietzscheano. Dioniso/Edipo/Zaratustra o San Pablo/Lutero son figuras paralelas, nunca personajes del todo históricos sino, como los personajes mitológicos, una constante fuente de referencias y pensamientos. Son abstracción. El Eurípides burgués es uno más de ellos, un portavoz de los peligros de la disolución artística, de los riesgos del cientifismo y de la decadencia modernas.

\section{Conclusiones}

En estas breves líneas que quedan, se van a resumir los principales aspectos esbozados en el presente artículo. Y tal y como se ha visto, el Eurípides nietzscheano es una figura terriblemente compleja, por lo que a la hora de analizarlo e interpretarlo hay que tener en cuenta lo siguiente:

- Es, en parte, producto de la formación filológica y estética de Nietzsche. Principalmente, a través de los hermanos Schlegel.

- Es dependiente, de forma filológicamente bastante cuestionable, de un corpus cerrado de fuentes (Aristófanes, Diógenes Laercio).

140. Nietzsche, F., "Historia de la literatura griega. Partes I y... p. 300.

141. Lesky, A., Historia de la literatura griega. Madrid 1985, p. 390.

142. Serrano, V., "Introducción... p. 34. 
- Está mediado por una intención, la de asociarlo a la «muerte de la tragedia», con lo que hay una construcción del discurso para que el personaje sirva a tal propósito.

El resultado es un Eurípides que rompió el precario equilibrio entre lo dionisiaco y lo apolíneo. Lo hizo, por un lado, como artista individual, con sus innovaciones técnicas. Por otro lado, no hizo sino representar a una época encarnada en Sócrates, el verdadero adversario para Nietzsche. Y a pesar de que Eurípides pudo representar para Nietzsche una contradicción, por su valor de fuente sobre lo dionisiaco, se pueden afirmar las siguientes conclusiones interpretativas para acabar:

- Eurípides es una idea, personaliza una tesis.

- Eurípides es un contendiente, Nietzsche quiere ser el principal portavoz del espíritu dionisiaco frente al trágico griego.

- Eurípides es un instrumento, el análisis crítico de la Modernidad es impensable sin esta figura como exemplum que guarda una lección. 